\title{
Influence of firing temperature on physical properties of Same clay and Pugu kaolin for ceramic tiles application
}

\author{
Hashimu Hamisi ${ }^{1}$, , Seungyong Eugene Park ${ }^{1}$, Byung-Hyun Choi ${ }^{2}$, Yong-Taie $\mathrm{An}^{2}$, Lee Jeongin ${ }^{2}$ \\ ${ }^{1}$ Dept. of Materials Science and Engineering, The Nelson Mandela African Institution of Science and Technology, Arusha, Tanzania \\ ${ }^{2}$ Electronic Ceramics Division, Korean Institute of Ceramic Engineering and Technology, Seoul, South Korea
}

\section{Email address:}

hamisih@nm-aist.ac.tz (H. Hamisi), eugene.park@nm-aist.ac.tz (S. E. Park), bhchoi@kicet.re.kr (Byung-Hyun C.)

\section{To cite this article:}

Hashimu Hamisi, Seungyong Eugene Park, Byung-Hyun Choi, Yong-Taie An, Lee Jeongin. Influence of Firing Temperature on Physical Properties of Same Clay and Pugu Kaolin for Ceramic Tiles Application. International Journal of Materials Science and Applications. Vol. 3, No. 5, 2014, pp. 143-146. doi: 10.11648/j.ijmsa.20140305.12

\begin{abstract}
This study focuses on the effect of firing temperature on the physical properties of Same clay and Pugu kaolin for potential application in ceramic tiles. X-Ray diffractometer (XRD) is used to analyze the phases formed after firing. XRD result shows that quartz, sillimanite and cristobalite appears at temperature beyond $1200^{\circ} \mathrm{C}$ while mullite phase develops in Pugu kaolin. Pugu kaolin shows low porosity $(1.3 \%)$ at $1400^{\circ} \mathrm{C}$ compared to that of Same clay $(12.7 \%)$. Water absorption at $1200^{\circ} \mathrm{C}$ is $7.8 \%$ for Pugu kaolin and sharply reduced to $0.47 \%$ at a temperature between $1300^{\circ} \mathrm{C}$ to $1400^{\circ} \mathrm{C}$ suggesting complete sintering to have taken place at this temperature.
\end{abstract}

Keywords: Clay, Ceramic Tile, Phase Development, Linear Shrinkage, Water Absorption

\section{Introduction}

Clay is the main raw material in the traditional ceramic industry and an important ingredient in advanced ceramic products. For example, clay is used as a raw material in many industrial fields such as ceramics, paper and paint. Their applications are closely dependent on their structure, composition, and physical properties [1-4].

Ceramic tiles are composed essentially of clays and other inorganic raw materials such as quartz, feldspar, and carbonates, the clays being the most important raw materials. In fabrication of ceramic products, raw materials selection plays vital role in the final [1]. The physico-chemical properties of the resulting ceramics is influenced by the properties of the components present in the clay and the temperature they have been subjected to [5]. During firing, a series of transformation occurs which determines their final ceramic properties $[6,7]$. Sintering of ceramic mass is fundamental in adjusting desired properties and occurs in general during liquid-phase formation. Thus the presence of components such as low-melting clays is very important. Fluxes (alkaline oxides, mainly $\mathrm{K}_{2} \mathrm{O}$ and $\mathrm{Na}_{2} \mathrm{O}$ ), in reaction with silica and alumina, promote liquid phase formations that facilitate densification [8].

For the purpose of determining the quality of the clays used in the formulation of ceramic tiles, it is important to monitor and understand the phase transformations which take place during the firing process [9].

Tanzania is importing industrial scale ceramic tiles and most of other related ceramic products from outside the country, as they are not adequately produced locally. There are, however, abundant ceramic raw materials locally available that can be exploited and utilized for such ceramic application. Clay deposits have been reported in places like Singino-Lindi, Pugu-Dar Es Salaam, Malangali-Iringa, and Matamba-Mbeya, Same-Kilimamjaro, Arusha and Mwanza have been reported [10-12]. Basically the studies have been on geolological occurrence and suggestions on their possible use. Pugu deposit found to be with white kaolinitic sandstone [10]. Neither deposit has been studied for the use in the ceramic tile industry. Thus, the knowledge of these clays has both academic value and immediate commercial interest in the ceramic tile industry.

This work is therefore to study the influence of firing temperature on physical properties of Same clay and Pugu kaolin for ceramic tile application. It focuses on the phase changes and microstructural development in relation to the physical properties due to change in firing temperature. 


\section{Experimental Procedure}

\subsection{Material}

Clay samples are collected from Same, Kilimanjaro region in the northern zone of Tanzania and Pugu kaolin hills approximately $25 \mathrm{~km}$ south-south-west of Dar es Salaam and $20 \mathrm{~km}$ inland from the Indian Ocean.

\subsection{Specimen Preparation}

Clay samples are planetary ball milled to form powder. The powder is pressed to form pellets which are dried at $105^{\circ} \mathrm{C}$ until constant weight was achieved. The samples are then heated to $600,800,1000,1200,1300$ and $1400^{\circ} \mathrm{C}$, respectively at a rate of $5^{\circ} \mathrm{C} / \mathrm{min}$ with soaking time of $1 \mathrm{~h}$ at each maximum temperature.

\subsection{Specimen Characterization}

The XRD patterns are obtained with Rigaku, D.Max 2200 diffractometer operating at tube voltage and current $40 \mathrm{kV}$ and $40 \mathrm{~mA}$, respectively using monochromatic $\mathrm{Cu}-\mathrm{K} \alpha$ radiation. Diffraction patterns were recorded by scanning from $10^{\circ}$ to $80^{\circ}(2 \theta)$ at a rate of $2^{\circ} / \mathrm{min}$. The morphology was observed by scanning electron microscopy (SEM), in JEOL JSM-6380.

The chemical composition of the samples is determined by inductively coupled plasma optical emission spectroscopy (ICP-OES) Optima 5300 DV. Linear shrinkage is calculated by measuring dimensions of the prepared specimen before and after firing as per BS EN ISO 1045-3:1997. Water absorption and apparent porosity are measured using Auto Pore IV 9500.

\section{Results and Discussion}

\subsection{Chemical Composition, Microstructures and Phase Analysis}

Table 1 shows the chemical compositions in terms of oxide contents, as well the loss on ignition of Pugu kaolin and Same clay. Both clays contain mainly $\mathrm{SiO}_{2}$ and $\mathrm{Al}_{2} \mathrm{O}_{3}$, which corresponds to $85.6 \%$ for Same clay and $83.6 \%$ for Pugu kaolin. Same clay shows the higher amount of $\mathrm{Fe}_{2} \mathrm{O}_{3}$ (2.62\%) compared to Pugu kaolin which contains $2.22 \%$ of $\mathrm{Fe}_{2} \mathrm{O}_{3}$ content. Iron oxide gives reddish color to the product after sintering and the reddish color becomes stronger as amount of $\mathrm{Fe}_{2} \mathrm{O}_{3}$ increases [13, 14].

Table 1. Chemical composition of raw materials (wt. \%)

\begin{tabular}{|c|c|c|c|c|c|c|c|c|c|c|}
\hline & $\mathrm{SiO}_{2}$ & $\mathbf{A l}_{2} \mathbf{O}_{3}$ & $\mathrm{Fe}_{2} \mathrm{O}_{3}$ & $\mathrm{TiO}_{2}$ & $\mathrm{CaO}$ & MgO & $\mathrm{Na}_{2} \mathrm{O}$ & $\mathrm{K}_{2} \mathrm{O}$ & LOI* & Total \\
\hline Pugu Kaolin & 48.9 & 34.7 & 2.22 & 0.6 & 0.01 & 0.11 & 0.07 & 0.34 & 13.05 & 100 \\
\hline Same Clay & 62.1 & 23.5 & 2.62 & 1.55 & 0.02 & 0.09 & 0.02 & 0.08 & 10.03 & 100 \\
\hline
\end{tabular}

*LOI=loss on ignition

The loss on ignition is observed to be relatively high for Pugu kaolin $(13.05 \%)$ compared to $(10.03 \%)$ that of clay from Same. The high loss on ignition $(13.05 \%)$ associated with low $\mathrm{SiO}_{2}$ and high $\mathrm{Al}_{2} \mathrm{O}_{3}$ content is due to the significant content of alumina in Pugu kaolin. The content of alkaline oxides $\left(\mathrm{K}_{2} \mathrm{O}\right.$ and $\left.\mathrm{Na}_{2} \mathrm{O}\right)$ is relatively low for Same clay indicating low percentage of flux minerals and that will result in increase in sintering temperatures $[2,15]$. The low earth-alkaline oxides $(\mathrm{CaO}$ and $\mathrm{MgO})$ content for Pugu kaolin and Same clay indicates that the studied clays are poor in carbonates [15].

The X-ray diffraction patterns of raw clay and after firing are presented in Figure.1. The result shows phase compositions of both raw clays are kaolinite but during firing phase changes are observed. Same clay forms quartz, cristobalite and sillimanite above $1200^{\circ} \mathrm{C}$. In Pugu kaolin, quartz starts to be formed above $1200^{\circ} \mathrm{C}$. Quartz and mullite phase dominates at a temperature above $1400^{\circ} \mathrm{C}$.

Past studies [3, 16, 17], shows that formation of mullite facilitated the densification. The present study gives results which agree with the phenomena presented, as Pugu kaolin densified much than Same clay (Table 2).

The examination of microstrure by Scanning Electron Microscope (SEM) presented in Figure 3 evidences the densification improvement when sintering is done.

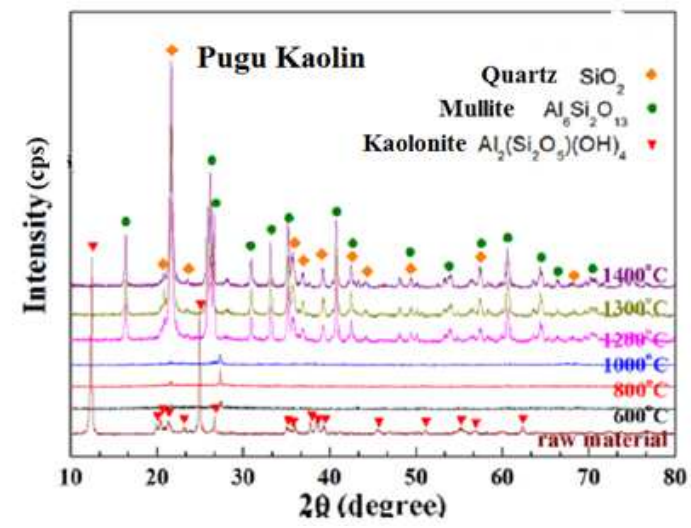

Figure 1. X-ray diffraction pattern of the clay sintered at various temperatures. 

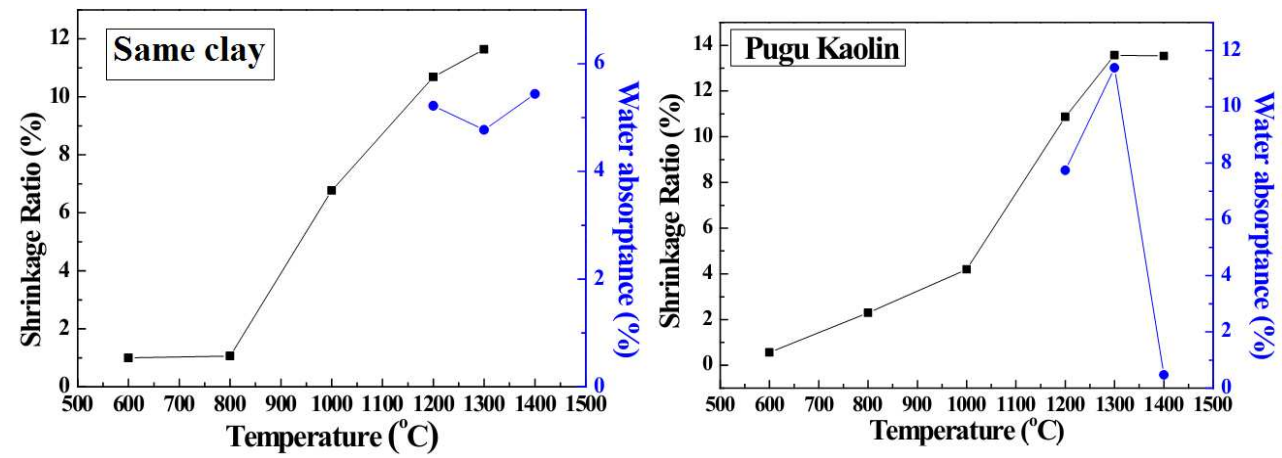

Figure 2. Water absorption and linear shrinkage of clay samples depending on sintering temperature
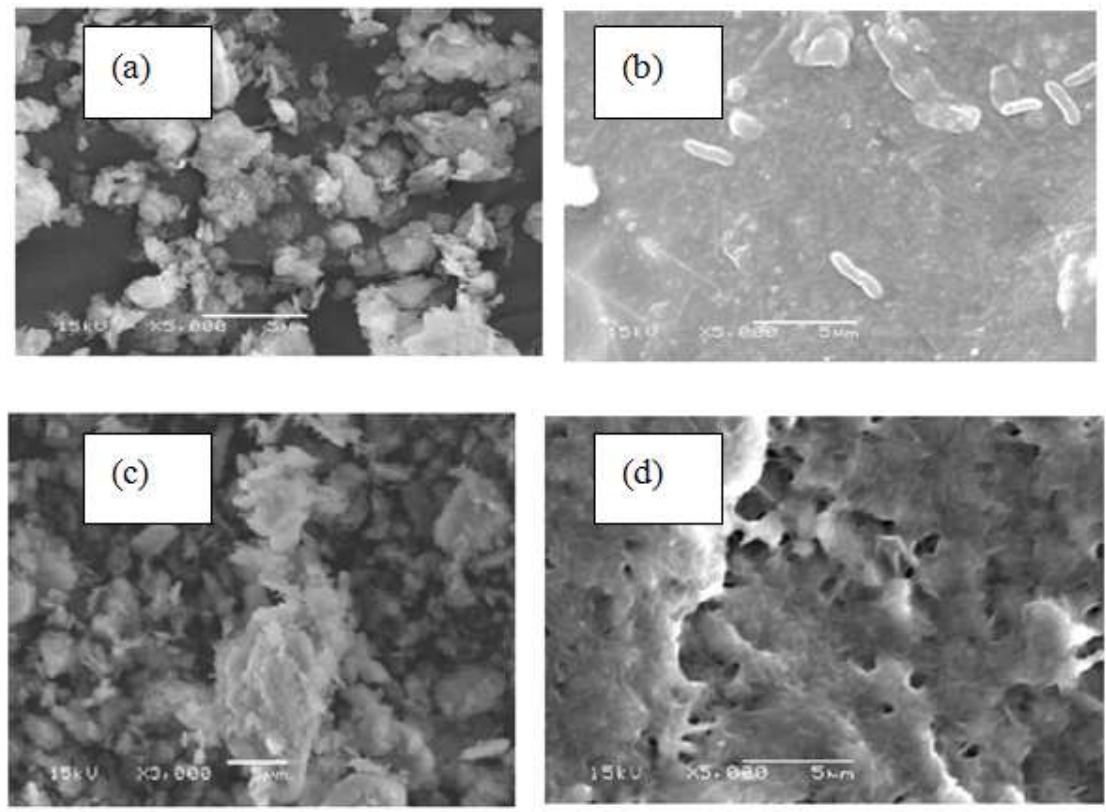

Figure 3. SEM micrographs of raw (a) Same clay, (c) Pugu kaolin and sintered at $1400^{\circ} \mathrm{C}$ (b) Same clay, (d) Pugu kaolin respectively

Table 2. Bulk properties of Pugu kaolin and Same clay depending on firing temperature

\begin{tabular}{|c|c|c|c|c|c|c|}
\hline \multirow[b]{2}{*}{$\begin{array}{l}\text { Heat-treatment } \\
\text { temperature }\left({ }^{\circ} \mathrm{C}\right)\end{array}$} & \multicolumn{3}{|l|}{ Pugu kaolin } & \multicolumn{3}{|l|}{ Same clay } \\
\hline & $\begin{array}{l}\text { Apparent density } \\
(\mathrm{g} / \mathrm{cm} 3)\end{array}$ & $\begin{array}{l}\text { Bulk density } \\
(\mathrm{g} / \mathrm{cm} 3)\end{array}$ & $\begin{array}{l}\text { Apparent } \\
\text { porosity (\%) }\end{array}$ & $\begin{array}{l}\text { Apparent density } \\
(\mathrm{g} / \mathrm{cm} 3)\end{array}$ & $\begin{array}{l}\text { Bulk density } \\
(\mathrm{g} / \mathrm{cm} 3)\end{array}$ & $\begin{array}{l}\text { Apparent } \\
\text { porosity (\%) }\end{array}$ \\
\hline 1200 & 2.742 & 2.261 & 17.5 & 2.673 & 2.345 & 12.3 \\
\hline 1300 & 2.725 & 2.079 & 23.7 & 2.724 & 2.41 & 11.5 \\
\hline 1400 & 2.676 & 2.642 & 1.3 & 2.679 & 2.338 & 12.7 \\
\hline
\end{tabular}

\subsection{Evaluation of Physical Properties}

Densification behavior, in terms of linear shrinkage and water absorption as a function of firing temperature is well presented in Figure.2. Results shows linear shrinkage increases as the firing temperature is increased. Water absorption values at $1200^{\circ} \mathrm{C}$ are $5.2 \%$ for Same clay and $7.8 \%$ for Pugu kaolin. The values are decreased to $0.47 \%$ and increased to $5.44 \%$ at $1400^{\circ} \mathrm{C}$ for Pugu kaolin and Same clay respectively.

The decrease in water absorption for Pugu kaolin is due to densification that has taken place. This is further evidenced by the sharp decrease in apparent porosity at firing temperature between $1300^{\circ} \mathrm{C}$ and $1400^{\circ} \mathrm{C}$ (Table 2). The increase in water absorption in Same clay at temperature between $1300^{\circ} \mathrm{C}$ and $1400^{\circ} \mathrm{C}$ as shown in Figure. 2 is due to increased apparent porosity which may be due to the formation of cristobalite which hinders easy densification of the component. These results are supported by El-Kheshen et al. [18] who investigated on sinterability, microstructure and properties of glass/ceramic composites and Zawrah et al. [17] who studied the effect of cristobalite formation on sinterability, microstructure and properties of glass/ceramic composites. On both studies, cristobalite phase precipitation in the composite lead to a more difficult densification.

\section{Conclusion}

Pugu kaolin is rich in kaolinite. During firing, quartz and 
mullite are formed. At room temperature, Same clay is kaolinite. As it is fired it phase transformation is observed. It forms quartz, sillimanite and cristobalite above $1200^{\circ} \mathrm{C}$. As the temperature is increased cristobalite peaks increases. The development of mullite phase in Pugu kaolin causes linear shrinkage increase with temperature while porosity and water absorption decreases. Water absorption values at firing temperature of $1400^{\circ} \mathrm{C}$ are $0.47 \%$ and $5.44 \%$ for Pugu kaolin and Same clay respectively. The sharp decrease in water absorption at a firing temperature between $1300^{\circ} \mathrm{C}$ and $1400^{\circ} \mathrm{C}$ in Pugu kaolin suggests the complete sintering to have been achieved at this temperature.

\section{References}

[1] H. Celik, "Technological characterization and industrial application of two Turkish clays for the ceramic industry," Applied Clay Science, vol. 50, pp. 245-254, 2010.

[2] C. Manoharan, P. Sutharsan, S. Dhanapandian, and R. Venkatachalapathy, "Characteristics of some clay materials from Tamilnadu, India, and their possible ceramic uses," Cerâmica, vol. 58, pp. 412-418, 2012.

[3] H. Baccour, M. Medhioub, F. Jamoussi, and T. Mhiri, "Influence of firing temperature on the ceramic properties of Triassic clays from Tunisia," Journal of Materials Processing Technology, vol. 209, pp. 2812-2817, 3/19/ 2009.

[4] H. H. Murray, "Overview-clay mineral applications," Applied Clay Science, vol. 5, pp. 379-395, 1991.

[5] M. Jordán, A. Boix, T. Sanfeliu, and C. De la Fuente, "Firing transformations of cretaceous clays used in the manufacturing of ceramic tiles," Applied Clay Science, vol. 14, pp. 225-234, 1999.

[6] S. Bragança and C. Bergmann, "A view of whitewares mechanical strength and microstructure," Ceramics International, vol. 29, pp. 801-806, 2003.

[7] I. Bakr, "Densification behavior, phase transformations, microstructure and mechanical properties of fired Egyptian kaolins," Applied Clay Science, vol. 52, pp. 333-337, 2011.
[8] A. Alcântara, M. Beltrão, H. Oliveira, I. Gimenez, and L. Barreto, "Characterization of ceramic tiles prepared from two clays from Sergipe-Brazil," Applied Clay Science, vol. 39, pp. 160-165, 2008.

[9] S. Sousa and J. Holanda, "Sintering Behavior of Porous Wall Tile Bodies During Fast Single-Firing Process," Materials Research, vol. 8, pp. 197-200, 2005.

[10] B. Schwaighofer and H. Muller, "MINERALOGY AND GENESIS OF THE PUGU HILL KAOLIN DEPOSIT, TANZANIA," Clay Minerals, vol. 22, pp. 401-9, 1987.

[11] SEAMIC, "MINERAL POTENTIAL OF SEAMIC MEMBER COUNTRIES.," Newspaper, vol. 10, January 2008.

[12] G.-I. E. Ekosse, "Kaolin deposits and occurrences in Africa: Geology, mineralogy and utilization," Applied Clay Science, vol. 50, pp. 212-236, 2010.

[13] E. Y. Lee, K.-S. Cho, and H. Wook Ryu, "Microbial refinement of kaolin by iron-reducing bacteria," Applied Clay Science, vol. 22, pp. 47-53, 2002.

[14] F. Milheiro, M. Freire, A. d. Silva, and J. Holanda, "Densification behaviour of a red firing Brazilian kaolinitic clay," Ceramics international, vol. 31, pp. 757-763, 2005.

[15] S. Monteiro and C. Vieira, "Influence of firing temperature on the ceramic properties of clays from Campos dos Goytacazes, Brazil," Applied Clay Science, vol. 27, pp. 229-234, 2004.

[16] A. El-Kheshen and M. Zawrah, "Sinterability, microstructure and properties of glass/ceramic composites," Ceramics international, vol. 29, pp. 251-257, 2003.

[17] M. Zawrah and E. Hamzawy, "Effect of cristobalite formation on sinterability, microstructure and properties of glass/ceramic composites," Ceramics international, vol. 28, pp. 123-130, 2002.

[18] A. A. El-Kheshen and M. F. Zawrah, "Sinterability, microstructures and properties of glass/ceramic composites," Ceramics International, vol. 29, 2003. 